JKM (Jurnal Kebidanan Malahayati),Vol 7,No.2.April 2021,

ISSN (Print) 2476-8944 ISSN (Online) 2579-762X, Hal 161-166

\title{
EFEKTIFITAS LACTACTION MASSAGE TERHADAP PENGELUARAN KOLOSTRUM PADA IBU NIFAS
}

\author{
Ainun Mardhiah ${ }^{1 *}$, Riska Maulidanita ${ }^{2}$, Winda Agustina $^{3}$ \\ 1,2,3Prodi Kebidanan Institut Kesehatan Helvetia \\ *Korespondensi email : ainun.syamaun@gmail.com
}

\section{ABSTRACT THE EFFECTIVENESS OF LACTACTION MASSAGE ON COLOSTRUM EXPENDITURE IN THE PUBLIC MOTHER}

Background :Breastfeeding immediately after delivery provides many benefits for mothers and children. Breast milk that comes out for the first time contains colostrum which is highly nutritious and has antibodies that can protect newborns from disease. Based on the Demographic and Health Survey (IDHS), it is stated that more than half of children (57\%) received breast milk within 1 hour after birth and 74 percent of children started breastfeeding within 1 day after birth.

Purpose :Knowing to analyzing the effectiveness of lactaction massage on colostrum expenditure in postpartum mothers

Methods:The research design used a pre-experimental design with a pretest-posttest control group design. Place of fresearch in the Medan City clinic in 2020.The population and sample in this study were all postpartum mothers on the first-third day totaling 24 people using purposive sampling technique. Comparison of 1: 1, where 12 respondents were intervened with lactaction massage and 12 respondents were the control group. The data that has been collected is processed by computer. Then analyzed the data, namely: Univariate and bivariate analysis using the Wilcoxon test with a significance level of 95\% (0.05).

Results: There is a difference in the average value of colostrum expenditure before and after the lactaction massage from 0.00 to 5.00. Wilcoxon test results obtained $p$ value $=0.007<0.05$.

Conclusion: There is the effectiveness of lactaction massage on colostrum expenditure in postpartum mothers.

Suggestion: it is advisable to mothers who give birth to know complete information about the importance of giving colosrum to newborns.

Keywords : Colostrum Expenditure, Lactaction Massage,Post Partum

\section{ABSTRAK}

Latar belakang: Pemberian ASI segera setelah melahirkan memberikan banyak manfaat bagi ibu dan anak. ASI yang keluar pertama kali mengandung kolostrum yang bergizi tinggi dan memiliki antibodi yang dapat melindungi bayi baru lahir dari penyakit. Berdasarkan Survei Demografi Dan Kesehatan (SDKI) menyatakan bahwa lebih dari separuh anak (57\%) mendapatkan ASI dalam periode 1 jam setelah lahir dan 74 persen anak mulai disusui dalam 1 hari setelah lahir.

Tujuan penelitian: untuk menganalisis efektifitas lactaction massage terhadap pengeluaran kolostrum pada ibu nifas.

Metode: Desain penelitian menggunakan metode pre eksperimental design dengan pretest-posttest control group design. Tempat penelitian di klinik Kota Medan Tahun 2020. Populasi dan sampel seluruh ibu nifas hari pertama-ketiga berjumlah 24 orang dengan menggunakan teknik purposive sampling. Perbandingan 1:1, dimana 12 responden diintervensi lactaction massage dan 12 responden sebagai kelompok kontrol. Data yang telah dikumpulkan, diolah dengan komputer. Kemudian menganalisis data yaitu: Analisis univariat dan bivariat dengan menggunakan uji t test dengan tingkat kemaknaan 95\% $(0,05)$.

Hasil: Terdapat perbedaan nilai rata-rata pengeluaran kolostrum sebelum dan setelah tindakan lactaction massage 0,00 menjadi 5,00. Hasil uji wilcoxon diperoleh nilai $p=0,007<0,05$.

Kesimpulan: Terdapat efektifitas lactaction massage terhadap pengeluaran kolostrum pada ibu nifas.

Saran: Peneliti selanjutnya untuk meneliti variabel lainnya terkait lactaction massage dan pentingnya pemberian kolostrum pada bayi baru lahir.

Kata Kunci: Pengeluaran Kolostrum, Lactaction Massage,Nifas 


\section{PENDAHULUAN}

Pemberian ASI segera setelah melahirkan memberikan banyak manfaat bagi ibu dan anak. Jika ASI tidak keluar setelah melahirkan menjadi salah satu penyebab bagi ibu untuk tidak mewujudkan pemberian ASI eksklusif (Hadriani and Hadati, 2019). ASI yang keluar pertama kali mengandung kolostrum yang bergizi tinggi dan memiliki antibodi yang dapat melindungi bayi baru lahir dari penyakit (Statistik Kependudukan and Nasional, 2017). Kolostrum dikeluarkan pada hari pertama setelah persalinan, jumlah kolostrum akan bertambah dan mencapai komposisi ASI biasa/matur sekitar 3-14 hari (Walyani and Purwoastuti, 2017). ASI mengandung semua nutrisi yang diperlukan bayi, terutama di awal kehidupannya (Ari and Adriani, 2015).

Berdasarkan Survei Demografi Dan Kesehatan (SDKI) tahun 2017 menyatakan bahwa lebih dari separuh anak (57\%) mendapatkan ASI dalam periode 1 jam setelah lahir dan 74 persen anak mulai disusui dalam 1 hari setelah lahir (Statistik Kependudukan and Nasional, 2017). Sedangkan Profil Kesehatan Indonesia tahun 2017 menjelaskan cakupan pemberian ASI $<1$ jam pertama yaitu $51,32 \%$ dan $\geq 1$ jam $6,65 \%$ khususnya provinsi Sumatera Utara mencapai pemberian $<1$ jam pertama yaitu $38,73 \%$ dan $\geq 1$ jam 3,47\% (Indonesia, 2018). Tahapan ASI pada hari pertama-tiga merupakan ASI kolostrum. Kolostrum adalah cairan pertama ASI yang dihasilkan selama masa kehamilan. Banyak ibu mengira bahwa kolostrum berwarna kuning keemasan/jingga, kental, lengket dan kadang bening yang diartikan sebagai susu basi dan kemudian dibuang (Nirwana, 2018)(Monika, 2018). Selain itu, banyak juga ibu yang khawatir kolostrum tidak akan cukup untuk bayi karena jumlahnya yang hanya sekitar 3-5 sendok teh sehingga perlu menambah susu formula. Padahal, walaupun jumlah kolostrum relatif sedikit, sudah sangat mencukupi lambung bayi yang juga memang masih kecil berkisar 5-27 ml (Ari and Adriani, 2015)(Monika, 2018).

Penyebab rendahnya pemberian ASI

Ekskusif salah satunya adalah penurunan produksi ASI pada hari-hari pertama setelah melahirkan dapat disebabkan oleh kurangnya rangsangan hormon oksitosin dan prolaktin yang sangat berperan dalam kelancaran produksi ASI, sehingga menyebabkan ASI tidak segera keluar setelah melahirkan, untuk mengeluarkan ASI dibutuhkan upaya nonfarmakologis berupa pijat oksitosin.Pijat oksitosin sangat membantu dalam proses pengeluaran ASI. Hasil penelitan dapat disimpulkan bahwa rerata waktu pengeluaran kelompok perlakuan 5.21 jam sedangkan rerata waktu pengeluaran kelompok kontrol $8.16 \mathrm{jam}$. Hasil uji TTest Independent nilai pvalue $=0.006$ yang berarti $p \leq 0.05$ menyatakan ada pengaruh pijat oksitosin terhadap rerata waktu pengeluaran kolostrum. (Wulandari, F. T., Aminin, F., \& Dewi, U.2016)

Apabila bayi tidak menghisap puting susu pada setengah jam setelah persalinan, hormon prolaktin dan oksitosin akan turun dan sulit merangsang hormon tersebut sehingga ASI baru keluar pada hari ketiga atau lebih (Sari, 2017). Oleh karena itu perlu adanya usaha yang dilakukan untuk meningkatkan kembali hormon tersebut. Usaha untuk merangsang hormon prolaktin dan oksitosin pada ibu setelah melahirkan selain dengan memeras ASI, dapat dilakukan juga dengan melakukan lactaction massage. lactaction massage adalah massage adalah pijatan pada kedua sisi tulang belakang durasi pemijatan 2-3 menit (Sari, 2017).

Berdasarkan hasil observasi pada 10 ibu nifas di klinik Kota Medan bahwa 4 ibu nifas yang menyusu bayinya setelah 6 jam post partum dan 6 ibu nifas memberikan susu formula pada bayinya serta mengatakan tidak ada usaha-usaha yang dilakukan untuk mengeluarkan ASI pertama (kolostrum). Berdasarkan uraian tersebut perlu dilakukan penelitian tentang efektifitas lactaction massage terhadap pengeluaran kolostrum pada ibu nifas Di Klinik Kota Medan Tahun 2020.

Tujuan penelitian untuk menganalisis efektifitas lactaction massage terhadap pengeluaran kolostrum pada ibu nifas di klinik Kota Medan Tahun 2020.

\section{METODE PENELITIAN}

Jenis penelitian eksperimental dengan pendekatan kuantitatif. Desain penelitian yang digunakan adalah pre-eksperimental design dengan rancangan one group pretest-posttest design (Hidayat, 2007). Kelompok intervensi diberikan perlakuan sebanyak 1 kali sehari selama 3 hari berturut-turut. Kelompok kontrol tidak diberikan perlakuan.

Waktu dan tempat penetian yaitu pada bulan Maret sampai dengan Oktober 2020 di 3 klinik Kota Medan yaitu: Klinik Dina beralamat di jalan Karya Dalam Kec. Medan Helvetia, RB Hanum beralamat di jalan Kl. Yos Sudarso no. $47 \mathrm{Kec}$. Medan Deli dan Klinik Rosdiana beralamat di jalan Panitera Kec. Medan Deli.

Populasi dan sampel dalam penelitian seluruh ibu nifas hari pertama-ketiga berjumlah 24 orang dengan menggunakan teknik purposive 
sampling. Perbandingan 1:1, dimana 12 responden diintervensi lactaction massage dan 12 responden sebagai kelompok kontrol. Kriteria inklusi sampel yaitu bersedia menjadi responden, lbu melahirkan anak pertama (primipara) dan ibu post partum hari pertama sampai dengan ketiga.

Variabel yg diteliti adalah lactaction massage dilakukan pada ibu nifas hari pertama-ketiga dengan 1 kali pijatan pada pagi hari selama 2-3 menit mengunakan baby oil dan dilakukan pijatan pada sepanjang kedua sisi tulang belakang sampai hari ketiga. Pengeluaran kolostrum diobservasi selama 3 hari yang dilakukan dengan cara pretest yaitu melihat berapa $\mathrm{ml}$ volume kolostrum yang keluar sebelum dilakukan pemijatan dan posttest yaitu melihat berapa $\mathrm{ml}$ volume kolostrum yang keluar setelah dilakukan pemijatan sebanyak 3 kali.

Data yang telah dikumpulkan, diolah dengan komputer. Kemudian menganalisis data yaitu: Analisis univariat untuk menggambarkan secara tunggal variabel lactaction massage dan pengeluaran kolostrum. Analisis bivariat untuk mengetahui analisis efektifitas breast dan lactaction massage terhadap pengeluaran kolostrum dengan menggunakan uji $t$ berpasangan jika data berdistribusi normal dan uji wilcoxon jika data tidak berdistribusi normal dengan tingkat kemaknaan 95\% $(0,05)$ (Dahlan, 2011)

\section{HASIL PENELITIAN}

Analisis univariat digunakan untuk melihat distribusi frekuensi karakteristik responden yaitu umur, pendidikan dan pekerjaan pada tabel 1 . Distribusi frekuensi pengeluaran kolostrum responden sebelum dan setelah diberikan lactaction massage dan kontrol pada tabel 2. Uji normalitas data dengan shapiro-wilk sebelum dan setelah dilakukan tindakan lactaction massage dan kontrol pada tabel 3. Efektifitas lactaction massage terhadap pengeluaran kolostrum pada ibu nifas pada tabel 4.

Hasil penelitian menunjukkan bahwa terdapat 24 responden pada umur, pendidikan dan pekerjaan. Pada kelompok lactaction massage dan kontrol mayoritas responden berumur 20-35 tahun berjumlah 9 orang $(75,0 \%)$ dan 6 orang $(50,0 \%)$.

Pada pendidikan menunjukkan bahwa pada kelompok lactaction massage dan kontrol mayoritas responden berpendidikan menengah 6 orang $(50,0 \%)$ dan 7 orang $(58,3 \%)$.

Dan pada pekerjaan menunjukkan bahwa pada kelompok lactaction massage dan kontrol mayoritas responden tidak bekerja berjumlah 8 orang $(66,7 \%)$ dan 7 orang $(58,3)$.
Tabel 1.

Distribusi Frekuensi Karakteristik Responden Lactaction Massage Dan

Kontrol Berdasarkan Umur, Pendidikan Dan Pekerjaan

\begin{tabular}{lcccc}
\hline \multirow{2}{*}{ Karakteristik } & \multicolumn{4}{c}{ Tindakan } \\
\cline { 2 - 5 } & \multicolumn{2}{c}{$\begin{array}{c}\text { Lactaction } \\
\text { Massage }\end{array}$} & \multicolumn{2}{c}{ Kontrol } \\
\cline { 2 - 5 } & $\mathbf{F}$ & $\%$ & $\mathbf{f}$ & $\%$ \\
\hline Umur & & & & \\
$<20$ tahun & 1 & 8,3 & 3 & 25,0 \\
$20-35$ tahun & 9 & 75,0 & 6 & 50,0 \\
$>35$ tahun & 2 & 16,7 & 3 & 25,0 \\
Pendidikan & & & & \\
Dasar & 1 & 8,3 & 3 & 25,0 \\
Menengah & 6 & 50,0 & 7 & 58,3 \\
Tinggi & 5 & 41,7 & 2 & 16,7 \\
Pekerjaan & & & & \\
Bekerja & 4 & 33,3 & 5 & 41,7 \\
Tidak bekerja & 8 & 66,7 & 7 & 58,3 \\
\hline Total & 12 & 100 & 12 & 100 \\
\hline
\end{tabular}

Tabel 2. Distribusi Frekuensi Pengeluaran Kolostrum Responden Sebelum

Dan Setelah Diberikan Lactaction Massage Dan Kontrol

\begin{tabular}{lcccc}
\hline \multirow{2}{*}{$\begin{array}{c}\text { Pengeluaran } \\
\text { Kolostrum }\end{array}$} & \multicolumn{4}{c}{ Tindakan } \\
\cline { 2 - 5 } & $\begin{array}{c}\text { Lactaction } \\
\text { Massage }\end{array}$ & \multicolumn{2}{c}{ Kontrol } \\
\cline { 2 - 5 } & $\mathbf{f}$ & $\%$ & $\mathbf{f}$ & $\%$ \\
\hline Sebelum & 3 & 25,0 & 4 & 33,3 \\
$0 \mathrm{cc}$ & 4 & 33,3 & 2 & 16,7 \\
$1 \mathrm{cc}$ & 2 & 16,7 & 3 & 25,0 \\
$2 \mathrm{cc}$ & 3 & 25,0 & 3 & 25,0 \\
$5 \mathrm{cc}$ & & & & \\
Setelah & 1 & 8,3 & 3 & 25,0 \\
$0 \mathrm{cc}$ & 2 & 16,7 & 3 & 25,0 \\
$1 \mathrm{cc}$ & 4 & 25,0 & 4 & 33,3 \\
$2 \mathrm{cc}$ & 2 & 16,7 & 2 & 16,7 \\
$5 \mathrm{cc}$ & 2 & 16,7 & 0 & 0,0 \\
$10 \mathrm{cc}$ & 1 & 8,3 & 0 & 0,0 \\
$15 \mathrm{cc}$ & 12 & 100 & 12 & 100 \\
\hline Total & & & & \\
\hline
\end{tabular}

Hasil penelitian menunjukkan bahwa terdapat 24 responden pada tindakan sebelum dan setelah diberikan Lactaction Massage dan kontrol. Pengeluaran kolostrum pada kelompok sebelum tindakan lactaction massage mayoritas $1 \mathrm{cc}$ berjumlah 4 orang $(33,3 \%)$ dan kontrol $0 \mathrm{cc}$ berjumlah 4 orang $(33,3 \%)$. 
Sedangkan pengeluaran kolostrum pada kelompok setelah diberikan lactaction massage $2 \mathrm{cc}$ berjumlah 4 orang $(33,3 \%)$ dan pada kelompok kontrol $2 \mathrm{cc}$ berjumlah 4 orang $(33,3 \%)$.

Tabel 3.

Uji Normalitas Data Dengan Shapiro-Wilk Sebelum Dan

Setelah Dilakukan Lactaction Massage Dan Kontrol

\begin{tabular}{lccc}
\hline \multirow{2}{*}{ Variabel } & \multicolumn{3}{c}{ Shapiro-Wilk } \\
\cline { 2 - 4 } & Statistic & Df & Sig. \\
\hline Lactaction massage & & & \\
Sebelum & 0,790 & 12 & 0,007 \\
Setelah & 0,822 & 12 & 0,017 \\
Kontrol & & & \\
Sebelum & 0,805 & 12 & 0,011 \\
Setelah & 0,823 & 12 & 0,017 \\
\hline
\end{tabular}

Hasil uji normalitas data dengan shapiro-wilk menunjukkan bahwa pada sebelum dilakukan lactaction massage dengan nilai sig. 0,007 sedangkan setelah dilakukan tindakan dengan nilai sig. 0,017. Disimpulkan bahwa nilai sebelum dan setelah tindakan lactaction massage lebih kecil dari 0,050 artinya data tersebut berdistribusi normal.

Sedangkan pada kelompok kontrol pada hari pertama dengan nilai sig. 0,011 sedangkan pada hari ketiga nilai sig. 0,017. Disimpulkan bahwa nilai pada kelompok kontrol lebih kecil dari 0,050 artinya data tersebut berdistribusi normal.

Tabel 4.

Efektifitas Lactaction Massage Terhadap Pengeluaran Kolostrum Pada Ibu Nifas

\begin{tabular}{|c|c|c|c|}
\hline \multirow[b]{2}{*}{ Variabel } & \multicolumn{3}{|c|}{ Pengeluaran Kolostrum } \\
\hline & $\begin{array}{c}\text { Rerata } \\
\text { Nilai }\end{array}$ & Nilai Z & $P$ \\
\hline \multicolumn{4}{|l|}{ Lactaction } \\
\hline \multicolumn{4}{|l|}{ Massage } \\
\hline Sebelum & 0,00 & 2699 & 0007 \\
\hline Setelah & 5,00 & 2.099 & 0,001 \\
\hline \multicolumn{4}{|l|}{ Kontrol } \\
\hline Sebelum & 4,00 & & \\
\hline Setelah & 3,00 & 0,333 & 0,139 \\
\hline
\end{tabular}

Berdasarkan hasil penelitian menunjukkan bahwa pada lactaction massage terdapat perbedaan nilai rata-rata pengeluaran kolostrum sebelum dan setelah tindakan lactaction massage 0,00 menjadi 5,00 . Hasil uji wilcoxon diperoleh nilai $p=0,007<0,05$, disimpulkan bahwa tindakan lactaction massage berpengaruh terhadap pengeluaran kolostrum pada ibu nifas.
Pada kontrol terdapat perbedaan nilai ratarata pengeluaran kolostrum pada hari pertama dan ketiga 4,00 menjadi 3,00 . Hasil uji wilcoxon diperoleh nilai $p=0,739>0,05$, disimpulkan bahwa kelompok kontrol tidak berpengaruh terhadap pengeluaran kolostrum pada ibu nifas.

\section{PEMBAHASAN}

Berdasarkan hasil penelitian yang telah dilakukan menunjukkan bahwa pada lactaction massage terdapat perbedaan nilai rata-rata pengeluaran kolostrum sebelum dan setelah tindakan lactaction massage 0,00 menjadi 5,00 dengan jumlah kolostrum sebelum dilakukan lactaction massage terendah $0 \mathrm{cc}$ dan tertinggi $5 \mathrm{cc}$ dan setelah dilakukan lactaction message terendah $0 \mathrm{cc}$ dan tertinggi $15 \mathrm{cc}$. Hasil uji wilcoxon diperoleh nilai $p=0,007<0,05$, disimpulkan bahwa tindakan lactaction massage berpengaruh terhadap pengeluaran kolostrum pada ibu nifas.

Penelitian ini sejalan dengan penelitian Endah and Masdinarsah, (2011) yang melaporkan bahwa jumlah kolostrum yang dikeluarkan kelompok perlakuan rata - rata 5,333 cc sedangkan kelompok kontrol adalah rata - rata 0,0289 cc sehingga, menujukkan pijat oksitosin berpengaruh terhadap jumlah produksi kolostrum dengan $p$-value 0,009 .

Penelitian lain menunjukkan hal yang sama, yaitu Wulan, (2019) menyatakan bahwa Nilai ratarata produksi ASI kelompok intervensi dengan analisis uji T-Paired dengan nilai $\alpha=0,05$ yaitu didapatkan nilai significancy $0,000<0,005$. Terdapat perbedaan rata-rata produksi ASI sebelum dan sesudah dilakukan kombinasi pijat oksitosin dan arometerapi lavender.

Menurut Asih tahun 2018 meningkatkan kualitas pelayanan bagi tenaga kesehatan terutama bidan sebagai pelaksana sehingga dapat meningkatkan pengetahuan ibu akan pijat oksitosin dan dapat memotivasi ibu dan keluarga untuk melakukan pijat oksitosin dan memberikan bimbingan serta penyuluhan kepada ibu nifas tentang manfaat pijat oksitosin

Penelitian lainnya oleh Wiwin Widayanti, (2014) juga mendapatkan hasil penelitian bahwa Metode SPEOS (stimulasi pijat endorphin, oksitosin dan sugestif) merupakan alternatif cara untuk masalah pengeluaran ASI terutama pada hari - hari pertama kehidupan bayi.

Disisi lain, penelitian oleh Diyan Indriyani dan Asmuji, (2017) yang menunjukkan bahwa kombinasi hypnobreastfeeding dan konsumsi blustru yang efektif untuk mengoptimalkan produksi 


\section{JKM (Jurnal Kebidanan Malahayati),Vol 7,No.2.April 2021, ISSN (Print) 2476-8944 ISSN (Online) 2579-762X, Hal 161-166}

kolostrum pada masa nifas ibu di RSD. Dr. Soebandi Jember.

Pijat oksitosin yang dilakukan di punggung ibu membawa kenyamanan bagi ibu. Secara fisiologis, ini mengaktifkan refleks oksitosin untuk mengeluarkan hormon oksitosin ke dalam darah. Oksitosin ini memungkinkan sel-sel mioepitel di sekitar alveoli berkontraksi dan menyebabkan ASI mengalir dari alveoli ke saluran ke dalam sinus dan puting susu dan bayi untuk menghisap. Semakin lancar pemrosesan ASI, semakin banyak ASI yang dihasilkan (Annisa, 2019).

Kolostrum merupakan cairan yang agak kental berwarna kekuning-kuningan (Pollard, 2017), lebih kuning dibanding dengan ASI mature, bentuknya agak kasar karena mengandung butiran lemak dan sel-sel epitel (Walyani and Purwoastuti, 2017)(Khasanah, 2013). Kolustrum juga dikenal dengan cairan emas yang encer berwarna kuning (dapat pula jernih) dan lebih menyerupai darah daripada susu karena mengandung sel hidup menyerupai sel darah hidup yang dapat membunuh kuman penyakit (Astutik, 2017). Kolostrum ini disekresi oleh kelenjar payudara pada 1-3 hari setelah melahirkan. Volume kolostrum sekitar 150$300 \mathrm{ml} / 24$ jam.(Yenie and Mugiati, 2017)

Teori berpendapat bahwa hal-hal yang merangsang pengeluaran kolostrum, salah satunya adalah dengan melakukan pijat oksitosin. Lactaction massage adalah pemijatan pada sepanjang kedua sisi tulang belakang. (Monika, 2018)

Pijat oksitosin merupakan salah satu prosedur non-farmakologis yang dapat dilakukan untuk memfasilitasi perkembangan ASI. Pijat dilakukan di sepanjang tulang belakang (vertebra) hingga tulang rusuk kelima-keenam (Martini, 2015)

Lactaction massage melalui neurotransmitter akan merangsang medulla oblongata langsung mengirim pesan ke hypotalamus di hipofise posterior untuk mengeluarkan oksitosin yang menyebabkan buah dada mengeluarkan air susunya. Pijatan juga akan merileksasikan ketegangan dan menghilangkan stres, sehingga hormon oksitosin keluar dan akan membantu pengeluaran air susu ibu. (Zamzara, Ernawati and Susanti, 2015) Selain itu, lactaction massage juga memiliki manfaat lain yaitu mempercepat proses involusi uteri.(Sutanto, 2018). Menurut Suryani 2013 Hasil Analisa bivariat menunjukan adanya perbedaan rata rata berat badan bayi dengan $p$ value : 0.001 ,ada perbedaan frekwensi BAK yang bermakna dengan $p$ value $=0,001$ dan ada perbedaan frekuensi menyusu yang bermakna dengan $p$ value $=0,001$ serta ada perbedaan lama tidur yang bermakna dengan $p$ value $=0,001$ ada pengaruh pijat oxytosin terhadap produksi ASI dengan indikasi berat badan bayi, frekwensi bayi menyusu, frekwensi bayi BAK dan lama bayi tidur setelah menyusu.

Pemberian pijat oksitosin oleh suami dapat meningkatkan produksi Air Susu Ibu (ASI) pada ibu nifas yang dilihat dengan berat badan bayi hari, frekuensi menyusui, lama tidur bayi, frekuensi Buang Air Besar bayi (BAB), frekuensi Buang Air Kecil bayi (BAK), dan istirahat tidur ibu.(Doko,2019).

Menurut asumsi peneliti, bahwa salah satu keberhasilan dalam pengeluaran kolostrum dengan lactaction massage. lactaction massage adalah tindakan pemijatan yang dilakukan pada tulang belakang pada punggung. Ketika dilakukan pemijatan tersebut maka neurotransmitter merangsang medulla oblongta yang kemudian mengirimkan pesan ke hypotalamus untuk mengeluarkan oksitosin sehingga pengeluaran kolostrum menjadi lancar. Sebagian besar ibu nifas merasakan manfaat pijat oksitosin dimana produksi ASI sebelum dilakukan pijat oksitosin menjadi lancar setelah dilakukan pijat oksitosin. Hal ini juga membuat ibu merasa rileks, lebih nyaman, dan kelelahan setelah melahirkan juga berkurang.(Maita,2016)

Disisi lain, ketika pengeluaran oksitosin memberikan kenyamanan kepada ibu, sehingga membantu ibu mempunyai pikiran dan perasaan positif terhadap bayinya serta mempercepat proses involusi uteri. Hal tersebut secara tidak langsung dapat mencegah terjadinya babyblues pada ibu. Selain itu, keberhasilan pengeluaran kolostrum juga didukung dari suami dan keluarga. Peran serta suami dan keluarga sebagai motivasi kepada ibu untuk membuat psikologis ibu menjadi baik dan tindakan pijatan tersebut dapat dilakukan oleh suami dan keluarga, sehingga dari pijatan tersebut menunjukkan bentuk kasih sayang dan sentuhan kepada ibu. Hal tersebut juga dapat mempercepat pengeluaran kolostrum.

Sedangkan faktor lainnya yaitu dalam peningkatan let down reflex adalah: melihat bayi, mendengarkan suara bayi, mencium bayi, memikirkan untuk menyusui bayi, memijat tulang belakang (pijat oxytocin). Sedangkan faktor-faktor yang menghambat let down reflex adalah stress seperti: keadaan bingung atau pikiran kacau, takut, dan cemas (Umbarsari, 2017).

\section{SIMPULAN}

Terdapat efektifitas lactaction massage terhadap pengeluaran kolostrum pada ibu nifas. 


\section{SARAN}

Hasil penelitian ini disarankan kepada peneliti selanjutnya untuk meneliti variabel lainnya terkait lactaction massage dan pentingnya pemberian kolosrum pada bayi baru lahir.

\section{UCAPAN TERIMAKASIH}

Ucapan terimakasih disampaikan kepada LLDIKTI yang telah memberikan dana selama proses penelitian berlangsung.

\section{DAFTAR PUSTAKA}

Annisa, M. (2019). PENGARUH EDUKASI TEKNIK MENYUSUI TERHADAP KEEFEKTIFAN IBU NIFAS DALAM MENYUSUI DI RS PKU MUHAMMADIYAH YOGYAKARTA (Doctoral dissertation, Universitas' Aisyiyah Yogyakarta).

Ari, D. R. K. and Adriani, F. R. (2015) Membesarkan Anak Hebat dengan ASI. Yogyakarta: Citra Media Pustaka.

Asih, Y. (2018). Pengaruh Pijat Oksitosin terhadap Produksi ASI pada Ibu Nifas. Jurnal IImiah Keperawatan Sai Betik, 13(2), 209-214.

Astutik, R. Y. (2017) Payudara dan laktasi. Jakarta: Salemba Medika.

Dahlan, M. S. (2011) Statistik untuk Kedokteran dan Kesehatan. Jakarta: Salemba Medika.

Doko, T. M., Aristiati, K., \& Hadisaputro, S. (2019). Pengaruh Pijat Oksitosin oleh Suami terhadap Peningkatan Produksi Asi pada Ibu Nifas. Jurnal Keperawatan Silampari, 2(2), 66-86.

Endah, S. N. and Masdinarsah, I. (2011) 'Pengaruh Pijat Oksitosin terhadap Pengeluaran Kolostrum pada Ibu Post Partum di Ruang Kebidanan Rumah Sakit Muhammadiyah Bandung Tahun 2011', Journal. Kesehatan. Kartika, pp. 1-9.

Hadriani, H. and Hadati, R. (2019) 'Efektivitas Pijat Oksitosin Dan Breast Care Pada Ibu Bersalin Terhadap Pengeluaran ASI Di Puskesmas Kamonii', Window of Health: Jurnal Kesehatan, pp. 218-230.

Hidayat, A. A. (2007) Metode Penelitian Kebidanan dan Teknik Analisis Data. Jakarta: Salemba Medika.

Indonesia, K. K. R. (2017) Data dan Informasi Profil Kesehatan Indonesia 2017. Indonesia.

Indriyani, D. and Asmuji, A. (2017) 'Analisis Perilaku Optimalisasi Produksi Asi Pada Ibu Postpartum Bekerja Dan Tidak Bekerja Di Wilayah Puskesmas Sumbersari Jember', Jurnal Penelitian IPTEKS, 2(2), pp. 148-153.

Khasanah, N. (2013) ASI atau Susu Formula ya.
Yogyakarta: FlashBooks.

Lestari, L., Widyawati, M. N. and Admini, A. (2018) 'Peningkatan Pengeluaran Asi Dengan Kombinasi Pijat Oksitosin Dan Teknik Marmet Pada Ibu Post Partum (Literatur Review)', Jurnal Kebidanan, 8(2), pp. 120129.

Maita, Liva. "Pengaruh pijat oksitosin terhadap produksi ASI." Jurnal Penelitian Kesehatan" SUARA FORIKES"(Journal of Health Research" Forikes Voice") 7, no. 3 (2016): 173-175.

Martini, D. E. (2015). Efektifitas Pijat Oksitosin terhadap Peningkatan Produksi ASI pada lbu. Surya, 20-25.

Monika, F. B. (2018) Buku Pintar ASI dan Menyusui. Jakarta: Noura Books.

Nirwana, A. B. (2018) ASI dan Susu Formula. Yogyakarta: Nuha Medika.

Pollard, M. (2017) ASI Asuhan Berbasis Bukti. Edited by M. H. dan E. Mardella. Jakarta: EGC.

Sari, R. N. (2017) 'Pengaruh Pijat Oksitosin Terhadap Lama Pengeluaran Kolostrum Pada lbu Post Sectio Caesaria Di RSUD Kota Madiun', Bidan Prada: Jurnal Publikasi Kebidanan Akbid YLPP Purwokerto.

Sebayang, W. B. R. (2017) 'Manfaat Massase Tengkuk dan Kompres Hangat Payudara terhadap Pengeluaran Kolostrum Asi pada Ibu Post Partum di Klinik Pratama Rosni Alizar Medan Tahun 2017', Jurnal IImiah Kebidanan Imelda, 3(2), pp. 267-270.

Statistik, B. P., Kependudukan, B. and Nasional, K. B. (2017) Survei Demografi dan Kesehatan Indonesia 2017, BPS. Jakarta.

Suciawati, A. (2018) 'Efektifitas Pijat Oksitosin terhadap Pengeluaran ASI pada Ibu Nifas', Jurnal IImu Kesehatan Masyarakat, 7(4), pp. 201-206.

Sutanto, A. V. (2018) Asuhan Kebidanan Nifas \& Menyusui Teori dalam Praktik Kebidanan Profesional. Yogyakarta: Pustaka Baru Press.

SURYANI, I. (2016). PIJAT PUNGGUNG TEKNIK EFFLEURAGE DENGAN MINYAK AROMATERAPI LAVENDER UNTUK PRODUKSI ASI IBU NIFASDI BPM SRI REJEKI WAHYUNINGSIH (Doctoral dissertation, STIKES MUHAMMADIYAH GOMBONG).

Umbarsari, D. (2017) 'Efektifitas Pijat Oksitosin Terhadap Pengeluaran ASI Di RSIA Annisa Tahun 2017', JI-KES (Jurnal IImu 
JKM (Jurnal Kebidanan Malahayati),Vol 7,No.2.April 2021,

ISSN (Print) 2476-8944 ISSN (Online) 2579-762X, Hal 161-166

Kesehatan), 1(1).

Walyani, E. S. and Purwoastuti, E. (2017) Asuhan Kebidanan Masa Nifas dan Menyusui. Yogyakarta: PT. Pustaka Baru.

Widayanti, W. (2014) 'Efektivitas Metode "Speos"(Stimulasi Pijat Endorphin, Oksitosin Dan Sugestif) Terhadap Pengeluaran Asi Pada Ibu Nifas:(Quasi Ekperimen, Di Bpm Wilayah Kabupaten Cirebon Tahun 2013)'. Program Pascasarjana Undip.

Wulan, M. (2019) 'Pengaruh Kombinasi Pijat Oksitosin Dengan Aromaterapi Lavender Terhadap Produksi ASI Pada lbu Post Partum Normal Di RSU Haji Medan Tahun
2018'.

Wulandari, F. T., Aminin, F. and Dewi, U. (2016) 'Pengaruh Pijat Oksitosin terhadap Pengeluaran Kolostrum pada lbu Post Partum di Rumah Sakit Umum Daerah Provinsi Kepulauan Riau', Jurnal Kesehatan, $5(2)$.

Yenie, H. and Mugiati, M. (2017) 'Hubungan Inisiasi Menyusui Dini (IMD) dengan Waktu Pengeluaran Kolostrum'.

Zamzara, R. F., Ernawati, D. and Susanti, A. (2015) 'Pengaruh Pijat Oksitosin Terhadap Waktu Pengeluaran Kolostrum lbu Post Partum Sectio Caesaria'. 